\title{
Pim-1 activation of cell motility induces the malignant phenotype of tongue carcinoma
}

\author{
SOUICHI TANAKA ${ }^{1,2}$, TETSUYA KITAMURA ${ }^{1}$, FUMIHIRO HIGASHINO $^{1}$, KYOKO HIDA $^{1}$, YOICHI OHIRO ${ }^{2}$, \\ MITSUNOBU ONO ${ }^{2}$, MASANOBU KOBAYASHI ${ }^{3}$, YASUNORI TOTSUKA ${ }^{2}$ and MASANOBU SHINDOH ${ }^{1}$ \\ Departments of ${ }^{1}$ Oral Pathology and Biology, and ${ }^{2}$ Oral and Maxillofacial Surgery, Hokkaido University \\ Graduate School of Dental Medicine, Sapporo 060-8586; ${ }^{3}$ Department of Fundamental Health Sciences, \\ School of Nursing and Social Services, Health Science University of Hokkaido, Hokkaido 061-0293, Japan
}

Received September 3, 2008; Accepted January 5, 2009

DOI: 10.3892/mmr_00000102

\begin{abstract}
Pim-1 is a serine/threonine kinase as well as a protooncogene that induces T-cell lymphoma. Pim-1 induces cell cycle progression in cooperation with c-Myc and acts as an inhibitor of apoptotic cell death, actions that are involved in blood cell oncogenesis. However, little is known regarding the role of Pim-1 in oral carcinogenesis. We investigated Pim-1 expression in tongue squamous cell carcinoma (SCC) and examined its clinicopathological features. Western blotting was performed in 6 oral SCC cell lines, with Pim-1 being detected in all 6 of the lines. Immunohistochemical detection of Pim-1 was carried out in 39 cases of tongue SCC and analyzed in terms of its associated clinicopathological features. Pim-1 was expressed in 17/39 cases of tongue carcinoma, and was significantly correlated with lymph node metastasis. The role of Pim-1 in cell motility was further examined in HSC3 cells using the GTP-binding assay for Rho family protein, the motility assay and siRNA treatment. Rac1 activation was observed, and cell motility was reduced when Pim-1 was knocked down by siRNA. These results indicate that Pim-1 is involved in the carcinogenesis of oral SCC and is correlated to metastasis, which is in part associated with the enhancement of cell motility.
\end{abstract}

\section{Introduction}

Squamous cell carcinoma (SCC) is the most common malignant tumor of the oral region (1), and oral SCC is the sixth most common carcinoma in the world $(2,3)$. Patients with oral SCC experience a low quality of life because the disease manifests functional abnormalities of digestion and speech. Moreover, oral SCC has a poor prognosis, with metastasis to regional lymph nodes and/or distant organs.

Correspondence to: Dr Masanobu Shindoh, Department of Oral Pathology and Biology, Hokkaido University Graduate School of Dental Medicine, N13 W7 Kita-ku, Sapporo 060-8586, Japan E-mail: mshindoh@den.hokudai.ac.jp

Key words: Pim-1. Rac1, motility, tongue carcinoma, metastasis
Pim-1 has been identified as the target of a murine leukemia provirus integration site $(4,5)$ that induces murine T-cell lymphoma. Human Pim-1, a homologue of murine Pim-1, has been cloned and shown to encode serine/threonine kinase, with a possible role in the neoplastic transformation of blood cells (6). Pim-1 is an effector of a cytokine signaling pathway, including IFN- $\gamma$, G-CSF, GM-CSF and interleukins, and is capable of inducing cell cycle progression by activating Cdc25A in cooperation with c-Myc (7) or by influencing the cellular localization of p21, a cyclin-dependent kinase inhibitor (8). It also acts as an inhibitor of apoptotic cell death in hematopoietic cells and enhances cell survival with Bcl-2 upregulation (9) and inactivation of the pro-apoptotic $\mathrm{BH} 3$ protein Bad (10). Thus, Pim-1 closely participates in blood cell oncogenesis; however, little is known regarding its role in the carcinogenesis of oral epithelial cells. We investigated Pim-1 expression in tongue SCC, with an emphasis on its clinicopathological features, especially in relation to factors affecting patient prognosis.

The invasive and metastatic potential of cancer cells is likely to affect the prognosis of cancer patients $(11,12)$. Thus, to improve prognosis, it is crucial to predict the metastatic potential of cancer cells prior to the initiation of cancer therapy. To date, various factors have been found to be involved in regulating metastasis. A number of these, correlating with cell proliferation, extracellular matrix degradation, cell death resistance, and others, have been considered. The motility of cancer cells is one of the potent factors associated with metastasis. Cytoskeletal filament organization causes the protrusion of the cell structures that induce cell movement. Rho family proteins are known to be involved in this mechanism. Cells in migration show membrane shapes of ruffling and filopodia at the leading edge with, respectively, Rac1 and Cdc42 activation $(13,14)$. In the present study, we examined Pim-1 expression and cell motility activity in an oral SCC cell line.

\section{Materials and methods}

Cell lines and culture conditions. The human oral SCC cell lines HSC2, HSC3, HSC4, Ca9.22, OSC20 and SAS (JCRB, Osaka, Japan) were used in the study. Cells were maintained in Dulbecco's modified Eagle's medium supplemented with $10 \%$ fetal bovine serum. 
Patients and tumors. A total of 39 patients who consulted the Oral Surgery Department of Hokkaido University Hospital between January 2001 and December 2004 and were diagnosed with T1 and T2 tongue SCC were examined. The clinical features of the sample are shown in Table I. There were 27 male and 12 female patients with a mean age of 62 years (range 35-83 years). TNM classification was conducted according to UICC criteria.

Immunohistochemical staining. A Pim-1 antibody was used to detect Pim-1 expression in oral carcinomas. Prior to its use in the clinical samples, we validated the ideal condition of the antibody using cell block samples. Pim-1-negative pancreas carcinoma KPN4 and colon carcinoma HCT117 cell lines, which were confirmed to express Pim-1, were harvested, fixed with $10 \%$ buffered formalin and embedded in paraffin according to routine histological examination procedures. Formalin-fixed paraffin-embedded tissue blocks were sectioned, dewaxed, rehydrated, and boiled in $10 \mathrm{mM}$ sodium citrate buffer ( $\mathrm{pH} \mathrm{6.0)}$ ) for $3 \mathrm{~min}$. Slides were incubated for $5 \mathrm{~min}$ in $0.3 \%$ hydrogen peroxide followed by $1 \%$ BSA for $10 \mathrm{~min}$. They were then exposed to primary rabbit polyclonal antibody for Pim-1 (Calbiochem, Tokyo, Japan) for $1 \mathrm{~h}$ at room temperature, followed by exposure to the Histofine Simple Stain PO (R) horseradish peroxidase-conjugated antirabbit secondary antibody (Nichirei, Tokyo, Japan) for $40 \mathrm{~min}$, then washed in PBS. Color was developed by incubation with the EnVision kit/HRP (DAB) (Dako, Tokyo, Japan). The slides were then counterstained with hematoxylin and mounted.

Statistical analysis. The independence of the clinical parameters and histological features (age, gender, tumor size and metastasis) of Pim-1 expression was examined using Fisher's exact test.

siRNA transfection targeting Pim-1. HSC3 cells were transiently transfected with a targeted sequence of Pim-1 siRNA (siPim-1) (Qiagen HP siRNA 1027400) using HiPerfect Transfection Reagent (Qiagen, Tokyo, Japan) according to the manufacturer's protocol. Control sequence siRNA (siControl, Qiagen) was also transfected into HSC3 cells as a negative control. Cells were subjected to immunoblotting and the migration assay after $48 \mathrm{~h}$.

Cell migration assay. HSC3 cells with control siRNA (nc) and siPim-1 were harvested and wounded by scraping. Phasecontrast images were captured at the $0,1,4$ and $8 \mathrm{~h}$ time points, and the width of the cell-free areas was measured. A Boyden chamber (BD-Discovery Labware, Bedford, MA, USA) was also used for the cell migration assay. HSC3 cells with control nc and cells with siPim-1 were seeded into the upper chamber, and EGF was added to the lower chamber as a chemoattractant. After $24 \mathrm{~h}$, the upper surfaces of the filters were wiped with a cotton swab, cells were stained with Giemsa, and the infiltrated cells were counted. All experiments were conducted in triplicate.

Immunoblotting. Cells were lysed in lysis buffer $[10 \mathrm{mM}$ Tris-HCl (pH 7.4), 5 mM EDTA, 150 mM NaCl, 10\% glycerol, $1 \%$ Triton $\mathrm{X}-100,0.1 \%$ SDS and protease inhibitor cocktail
(Roche, Indianapolis, IN, USA)] for $20 \mathrm{~min}$ on ice and clarified by microcentrifugation. The supernatant was subjected to SDS-PAGE and transferred to polyvinylidene difluoride membranes (Bio-Rad, Hercules, CA, USA). A Pim-1 rabbit polyclonal antibody (Calbiochem, Tokyo, Japan) was used for Pim-1 detection in cultured oral SCC cell lines. Rac1 and Cdc42 mouse monoclonal antibodies (Upstate, Tokyo, Japan) were employed for the GTP pull-down assay.

GTP pull-down assay. Rac1/Cdc42 activity was analyzed with the Rac/Cdc42 Activation Kit (StressXpress ${ }^{\mathrm{TM}}$; Stressgen Bioreagents, Ann Arbor, MI, USA) according to the manufacturer's instructions.

In brief, after washing cells were lysed in assay buffer and centrifuged to remove cell debris. To determine total Rac1/ Cdc42 levels, $40 \mu 1$ of each sample was stored at $-80^{\circ} \mathrm{C}$ for separate analysis. The remaining $700 \mu \mathrm{l}$ of the supernatant (containing $500 \mu \mathrm{g}$ of total protein) was incubated with $10 \mu \mathrm{g}$ of the agarose-conjugated p21-binding domain of p21-activated protein kinase-1, which binds both activated Rac1 and Cdc42, for $1 \mathrm{~h}$ at $4^{\circ} \mathrm{C}$ with gentle rocking. Agarose beads that bound active $\operatorname{Rac} 1 / \mathrm{Cdc} 42$ were washed 4 times in assay buffer, resuspended in $50 \mu 1$ of $2 \mathrm{X}$ SDS sample buffer, and boiled at $95^{\circ} \mathrm{C}$ for $5 \mathrm{~min}$. Active (GTP-bound) and total Rac1/Cdc42 protein levels in each sample were analyzed by Western blotting. All blots were visualized using the ECL Detection System (Amersham Biosciences Corp., NJ, USA).

\section{Results}

Pim-1 protein is expressed in oral squamous cell carcinoma cell lines. To address the role of Pim-1 in oral carcinogenesis, we first examined whether it was expressed in the oral carcinoma cell lines HSC2, HSC3, HSC4, OSC20, Ca9.22 and SAS, analyzed using Western blotting. All cell lines expressed Pim-1 protein, with HSC3 and SAS exhibiting especially high levels. No obvious expression was observed in the normal human gingival fibroblasts used as a negative control (Fig. 1).

Pim-1 expression in tongue squamous cell carcinomas is related to cancer metastasis. A total of 39 tongue carcinoma cases were examined. They comprised 11 cases of $\mathrm{T} 1$ and 28 cases of T2, 37 cases of N0 and 2 of N2, and 37 cases of M0 and 2 of M1 according to the initial clinical TNM classification. During the follow-up period, subsequent lymph node metastasis occurred in 10 patients, and distant metastasis in 6 of the N0 and M0 cases, respectively. Patient prognoses were as follows: 13 succumbed to their tumors, 2 succumbed to other factors, and 23 are alive without tumors. The prognosis of 1 case is unknown as the patient ceased consulting the hospital during the 5-year follow-up period (Table I). Prior to addressing the clinical cases, we determined the immunohistochemical detection conditions with cell block materials constructed using a procedure similar to that used for routine pathological specimens. KPN4, a Pim-1-negative pancreas carcinoma cell line, and HCT117, a Pim-1-positive colon carcinoma cell line, were used. No obvious Pim-1-positive signal was observed in KPN4 cells (Fig. 2A), but Pim-1 was detected in the nuclei of HCT117 cells (Fig. 2B) under the conditions described in Materials and methods. Immuno- 
Table I. Clinicopathological features of the examined cases.

\begin{tabular}{|c|c|c|c|c|c|}
\hline Case & Age/gender & pTNM & Subsequent metastasis & Prognosis & Pim-1 \\
\hline 1 & $47 / \mathrm{M}$ & T2N0M0 & +; Regional lymph nodes & Deceased due to tumor & + \\
\hline 2 & $50 / \mathrm{M}$ & $\mathrm{T} 2 \mathrm{~N} 2 \mathrm{bM} 0$ & + ; Distant organ & Deceased due to tumor & + \\
\hline 3 & $48 / \mathrm{M}$ & T1N0M0 & - & Alive & + \\
\hline 4 & $76 / \mathrm{F}$ & T2N0M0 & - & Alive & + \\
\hline 5 & $74 / \mathrm{M}$ & T2N0M0 & - & Alive & + \\
\hline 6 & $71 / \mathrm{F}$ & T2N0M0 & - & Alive & + \\
\hline 7 & $58 / \mathrm{M}$ & T2N0M0 & - & Alive & + \\
\hline 8 & $62 / \mathrm{M}$ & T2N0M0 & - & Alive & + \\
\hline 9 & $76 / \mathrm{M}$ & T2N0M1 & $+;$ Regional lymph nodes & Deceased due to tumor & + \\
\hline 10 & $66 / \mathrm{M}$ & $\mathrm{T} 2 \mathrm{~N} 2 \mathrm{M} 1$ & - & Deceased due to tumor & + \\
\hline 11 & $51 \mathrm{M}$ & T2N0M0 & +; Regional lymph nodes, distant organ & Deceased due to tumor & + \\
\hline 12 & $69 / \mathrm{M}$ & T2N0M0 & + ; Regional lymph nodes, distant organ & Deceased due to tumor & + \\
\hline 13 & $35 / \mathrm{M}$ & T2N0M0 & + ; Distant organ & Deceased due to tumor & + \\
\hline 14 & $51 / \mathrm{M}$ & T2N0M0 & +; Distant organ & Deceased due to tumor & + \\
\hline 15 & $73 / \mathrm{F}$ & T2N0M0 & +; Regional lymph nodes & Deceased due to tumor & + \\
\hline 16 & $74 / \mathrm{F}$ & T1N0M0 & +; Regional lymph nodes & Deceased due to tumor & + \\
\hline 17 & $67 / F$ & T2N0M0 & - & Alive & + \\
\hline 18 & $67 / \mathrm{M}$ & T1N0M0 & +; Regional lymph nodes & Alive & - \\
\hline 19 & $63 / \mathrm{M}$ & T2N0M0 & - & Alive & - \\
\hline 20 & $72 / \mathrm{F}$ & T2N0M0 & - & Alive & - \\
\hline 21 & $67 / F$ & T1N0M0 & - & Alive & - \\
\hline 22 & $68 / \mathrm{M}$ & T2N0M0 & - & Alive & - \\
\hline 23 & $50 / \mathrm{M}$ & T2N0M0 & - & Alive & - \\
\hline 24 & $66 / \mathrm{M}$ & T2N0M0 & +; Regional lymph nodes, distant organ & Deceased (other factor) & - \\
\hline 25 & $45 / \mathrm{M}$ & T1N0M0 & - & Alive & - \\
\hline 26 & $60 / \mathrm{M}$ & T1N0M0 & - & Deceased (other factor) & - \\
\hline 27 & $68 / \mathrm{M}$ & T2N0M0 & - & Alive & - \\
\hline 28 & $83 / \mathrm{F}$ & T2N0M0 & +; Regional lymph nodes & Deceased due to tumor & - \\
\hline 29 & $66 / \mathrm{M}$ & T1N0M0 & - & Alive & - \\
\hline 30 & $28 / \mathrm{F}$ & T2N0M0 & - & Alive & - \\
\hline 31 & $69 / \mathrm{M}$ & T2N0M0 & - & Alive & - \\
\hline 32 & $65 / F$ & T1N0M0 & - & Alive & - \\
\hline 33 & $63 / \mathrm{M}$ & T2N0M0 & - & Alive & - \\
\hline 34 & 69/M & T1N0M0 & - & Alive & - \\
\hline 35 & $48 / \mathrm{M}$ & T1N0M0 & - & Alive & - \\
\hline 36 & $62 / \mathrm{M}$ & T2N0M0 & - & Deceased due to tumor & - \\
\hline 37 & $48 / \mathrm{F}$ & T1N0M0 & +; Regional lymph nodes & Unkown & - \\
\hline 38 & $65 / F$ & T2N0M0 & - & Deceased due to tumor & - \\
\hline 39 & 78/M & T2N0M0 & - & Alive & - \\
\hline
\end{tabular}

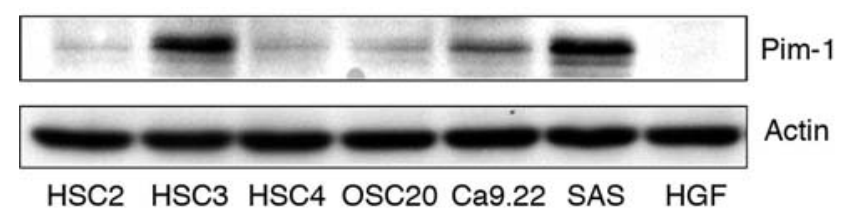

Figure 1. Western blot analysis of Pim-1 expression in oral squamous cell carcinoma cell lines. Pim-1 is observed in 6 oral carcinoma cell lines with slight (HSC2, HSC4, OSC20), moderate (Ca9.22) and high (HSC3, SAS) levels of expression. HGF serves as a negative control. histochemical detection of Pim-1 was performed for 39 tongue SCCs. Nuclear Pim-1-positive signals (Fig. 2C) were observed in 17 of the 39 cases. The remaining 22 were Pim-1 negative. Primary and subsequent lymph node metastases were present in 12 cases, and distant metastasis was observed in 8 cases. Metastasis in the lymph nodes and/or distant organs was observed in 14/39 cases. Among the Pim-1-positive cases, 10/17 exhibited significantly high metastatic activity, whereas among the Pim-1-negative cases only $4 / 22$ did $(\mathrm{p}<0.005)$ 


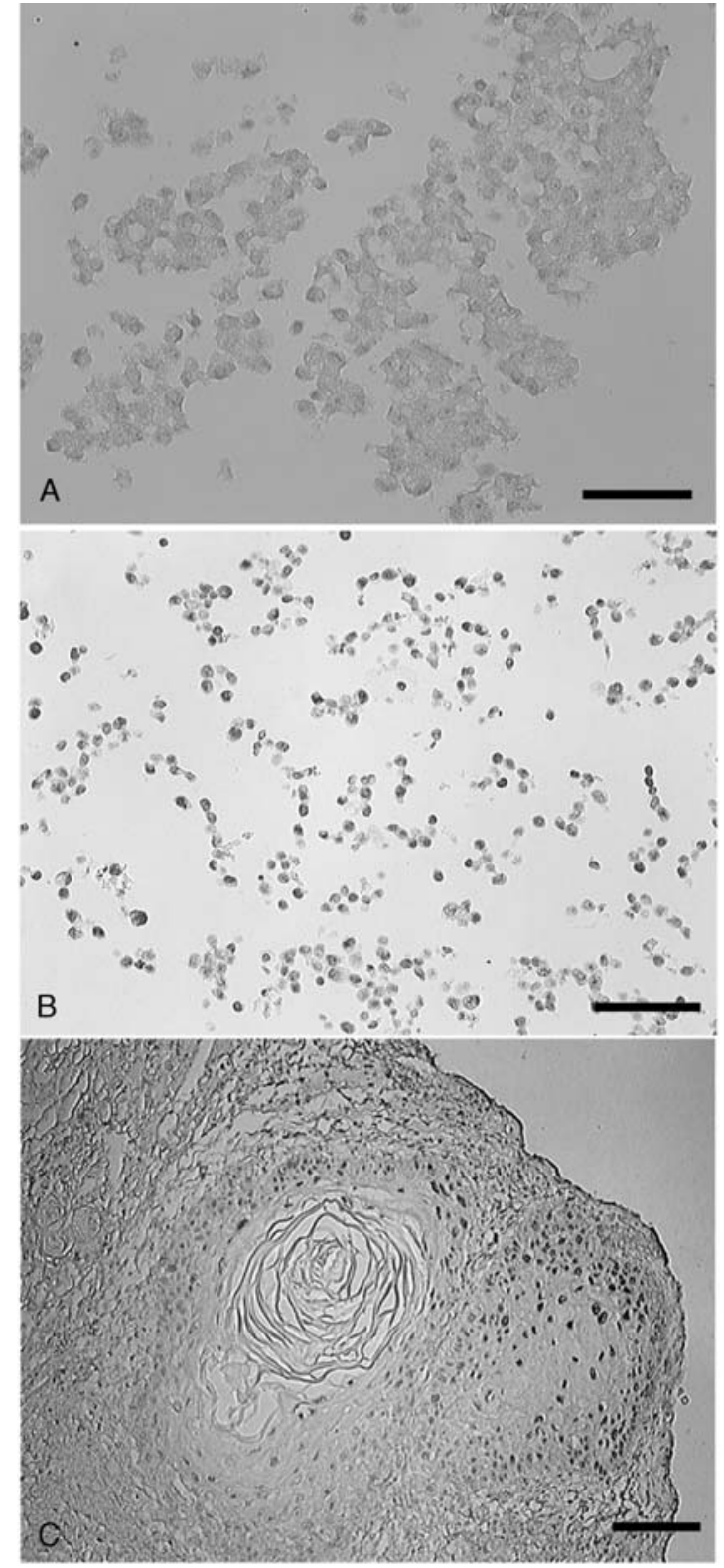

Figure 2. Immunohistochemical detection of Pim-1. (A) No obvious Pim-1positive signal was observed in KPN4, a Pim-1-negative pancreas carcinoma cell line. (B) Pim-1 was detected in the nuclei of HCT117 cells, a Pim-1-positive colon carcinoma cell line. (C) A Pim-1-positive case of tongue squamous cell carcinoma (case 9, Table I) exhibiting nuclear Pim1-positive signals. Bar, $200 \mu \mathrm{m}$.

(Fig. 3). All 10 of the Pim-1-positive and metastasis-burdened patients succumbed to their tumors, whereas 3/22 Pim-1negative patients experienced a poor clinical course with tumors. No significant association was noted between age or gender and Pim-1 expression.

Pim-1 is associated with cell motility through its activation of Rac-1. The role of Pim-1 was further explored using HSC3 cells to examine cell motility. siPim-1-transfected HSC3 cells and HSC3 cells transfected with the negative control sequence of siPim-1 (Cont) were used for the experiments. HSC3 cells transiently transfected with siPim-1 exhibited reduced expression of Pim-1 protein (Fig. 4A). Cell motility was examined by wound-healing and Boyden chamber assays. Repair of the cell monolayer after wounding slowed upon

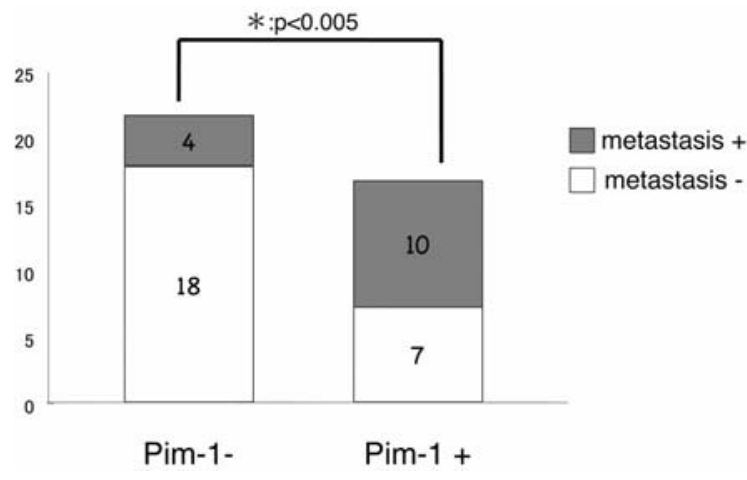

Figure 3. Statistical analysis of Pim-1 expression and metastasis. A significant correlation between Pim-1 expression and metastasis of tongue squamous cell carcinoma was noted.

siPim-1 treatment compared to the control (Fig. B). The width of migrating cells in the scratch wound was significantly narrower in siPim-1-treated HSC3 cells (Fig. 4C). Furthermore, the migration assay using the Boyden chamber revealed that siPim-1-treated HSC3 cells had an $\sim 50 \%$ reduction in motility in comparison to control cells (Fig. 4D). This difference was statistically significant $(\mathrm{p}<0.001)$. Thus, knock-down of Pim-1 extensively suppressed the malignant phenotypes of cell motility in HSC-3 cells.

Next, motility-associated protein expression was examined. The Rho family of GTPases are members of the small G protein family, and change from a GDP-bound inactive form to a GTP-bound active form. In this study, we tested GAP activity using a standard GTPase assay of Rac1 and Cdc42 using immunoprecipitation from HSC3 cells transfected with control siRNA or siRNA for Pim-1. EGF stimulation (100 ng/ml) was conducted to induce cell motility, as HSC3 cells have been shown to possess an EGF receptor that induces cell migration. The GTP-binding assay for Rho family proteins revealed that HSC-3 cells with siRNA for Pim-1 reduced Pim-1 protein expression (siPim-1). EGF stimulation increased the expression of GTP-bound active Rac-1 and Cdc42. Active-Rac-1 expression decreased when cells were treated with siPim-1, although the expression level of Cdc42 was not affected by siPim-1 treatment (Fig. 5).

\section{Discussion}

Pim-1 was originally identified as a proviral integration region of the murine leukemia virus (4), and was shown to be involved in the tumorigenesis of T-cell lymphoma in cooperation with c-Myc $(15,16)$. Pim-1 is a serine/threonine kinase, and has been shown to induce cell proliferation via Cdc25A phosphorylation (7) and the inactivation of $\mathrm{p} 21^{\text {wafl/cip } 1}$ (17). Pim-1 inhibits apoptotic cell death by inactivating the pro-apoptotic protein Bad and by enhancing Bcl-2 activity (10). These biological featuresare involved in the mechanism of blood cell tumorigenesis, and thus Pim-1 is thought to be a proto-oncogene. Many reports have therefore focussed on the significance of Pim-1 in blood cell tumorigenesis $(4,15,18,19)$; however, little is known regarding its role in solid tumors, with the exception of prostate carcinogenesis (20-22). We first examined whether Pim-1 was expressed in oral SCC using oral SCC-derived cell lines. It was noted that Pim-1 was 
A

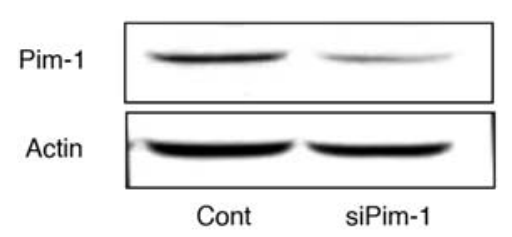

B

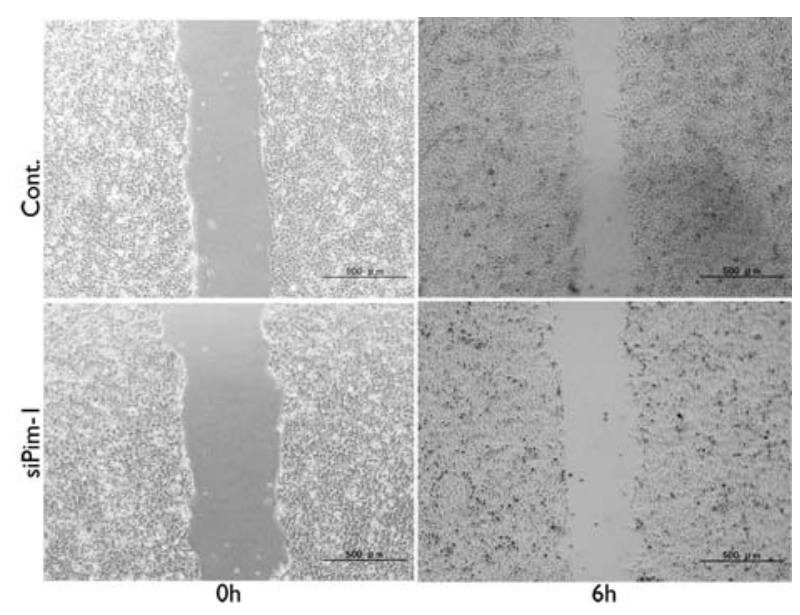

C

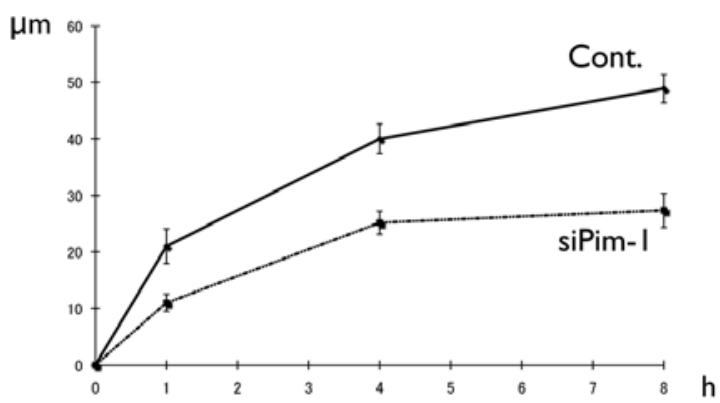

D

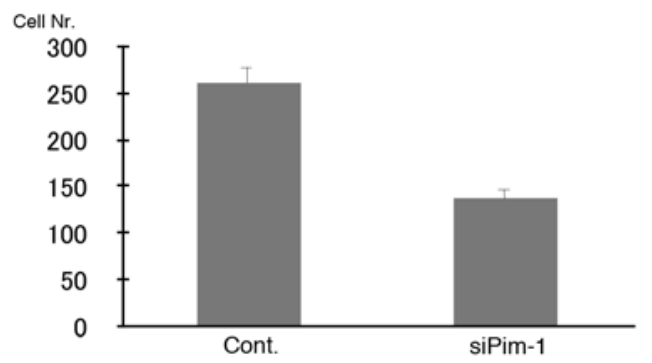

Figure 4. siRNA for Pim-1 induced Pim-1 knockdown which suppressed cancer cell motility. (A) Reduced expression of Pim-1 is observed in HSC3 cells by transfection of siRNA for Pim-1. (B) The wound-healing assay shows that repair of the cell monolayer after wounding slowed with siPim-1 treatment compared to the control. Bar, $500 \mu \mathrm{m}$. (C) The migrating length is significantly narrower in HSC3 cells. (D) The migration assay using the Boyden chamber revealed that siPim-1-treated HSC3 cells had an $~ 50 \%$ reduction in motility in comparison to control cells. This difference was statistically significant $(\mathrm{p}<0.001)$.

expressed in all 6 different oral SCC cell lines, indicating the significance of Pim-1 in oral epithelial cell carcinogenesis or malignant phenotype expression.

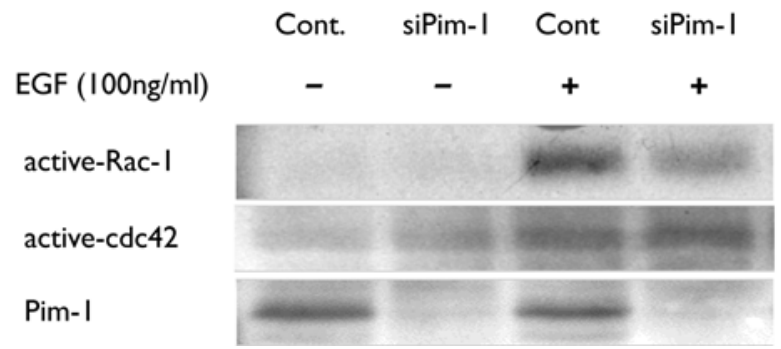

Figure 5. The active form of Rac-1 is reduced by Pim-1 knockdown. The GTP-binding assay for Rho family proteins revealed that HSC-3 cells with siRNA for Pim-1 reduced Pim-1 protein expression (siPim-1). EGF stimulation $(100 \mathrm{ng} / \mathrm{ml})$ increased expression of both GTP-bound active Rac-1 and Cdc42. Active-Rac-1 expression decreased when cells were treated with siPim-1, although the expression level of Cdc42 was not affected by siPim-1 treatment.

In the present study, we investigated Pim-1 expression in patients with tongue SCC. Immunohistochemical detection of Pim-1 in the routine paraffin-embedded biopsy sections from the patients revealed that $17 / 39$ cases were Pim-1-positive and the other 22 Pim-1-negative. These results suggest that Pim-1 expression in tongue SCC is highly correlated with tumor metastasis to the cervical lymph nodes and distant organs. Significantly high metastatic activity was observed in 10/17 Pim-1-positive cases, but in only 4/22 Pim-1-negative cases in the early phase of T1 and T2 tongue SCC. Pim-1 expression was related to a poor prognosis, as all 10 Pim-1-positive and metastasis-burdened patients succumbed to their tumors. Tumor metastatic potential is estimated by histological examination. Poorly differentiated cancers with infiltrative growth are considered to have high metastatic potential. However, unexpected metastasis in tumors that are histologically well differentiated and show expansive growth is sometimes noted. Our results indicate that Pim-1-expressing tongue SCC has latent potential for metastasis, even in histologically lowmalignancy cancers.

Metastasis is a complex process that includes tumor cell invasion of adjacent and vascular tissues, tumor cell dissemination through blood or lymph vessels, escape from apoptosis in anoikis, extravasation from vessels and growth in secondary organs (23-25). Tumor cell migration is the essential step of metastasis. Active migration of cancer cells causes intravasation into blood or lymphatic vessels $(11,26,27)$, which is the initial step of the oral SCC metastatic cascade. Cell motility is an important factor in cancer cell migration. Autocrine and paracrine factors, such as hepatocyte growth factor, have also been identified (28-30). However, there have been no reports on Pim-1 and cell motility activation. Our results indicate that Pim-1 is closely correlated with cell motility. The knockdown of Pim-1 in HSC 3 cells resulted in a significant reduction in motility, confirmed by cell scratch and Boyden chamber assays.

Rho family proteins belong to the Ras superfamily of small GTPases, which are key regulators of cell polarity and motility. Rho, Rac1 and Cdc42 are the main members of the Rho protein family, and Rac1 and Cdc42 can respectively induce cytoplasmic protrusions, known as lamellipodia and filopodia, by stimulating actin polymerization (31). Rac1 activates the WAVE protein complex that induces Arp2/3 
complex-mediated actin polymerization in lamellipodia formation (32). Cdc42 forms filopodia by activating Dia, which induces actin polymerization in parallel bundles $(33,34)$. Both Rac1 and Cdc42 are closely associated with cell motility by altering the structure of the leading edge of the plasma membrane. Rho family proteins bind to GTP and GDP, and these GTP-bound Rho family proteins activate downstream target proteins. Our results reveal that Pim-1 enhances Rac1 activity, which would affect the cytoskeleton filament organization that intermediates cell motility and cause the high metastatic ability of oral SCC.

The present study elucidates the role of Pim-1 in oral SCC. Our results suggest that Pim-1 expression in oral SCC is a predictive factor for metastasis, as it activates cancer cell motility in even the early stages of cancer development. Pim-1 is therefore a promising molecule for gene-targeting therapy.

\section{Acknowledgements}

This study was supported, in part, by grants-in-aid for scientific research from the Ministry of Education, Culture, Sports, Science and Technology of Japan.

\section{References}

1. Kudo Y, Kitajima S, Ogawa I, Miyauchi M and Takata T: Downregulation of Cdk inhibitor p27 in oral squamous cell carcinoma. Oral Oncol 41: 105-116, 2005.

2. Choi S and Myers JN: Molecular pathogenesis of oral squamous cell carcinoma: implications for therapy. J Dent Res 87: 14-32, 2008.

3. Hunter KD, Parkinson EK and Harrison PR: Profiling early head and neck cancer. Nat Rev Cancer 5: 127-135, 2005.

4. Cuypers HT, Selten G, Quint W, Zijlstra M, Maandag ER, Boelens W, van Wezenbeek P, Melief C and Berns A: Murine leukemia virus-induced T-cell lymphomagenesis: integration of proviruses in a distinct chromosomal region. Cell 37: 141-150, 1984.

5. Tsichlis PN: Oncogenesis by Moloney murine leukemia virus. Anticancer Res 7: 171-180, 1987.

6. Padma R and Nagarajan L: The human PIM-1 gene product is a protein serine kinase. Cancer Res 51: 2486-2489, 1991

7. Mochizuki T, Kitanaka C, Noguchi K, Muramatsu T, Asai A and Kuchino Y: Physical and functional interactions between Pim-1 kinase and Cdc25A phosphatase. Implications for the Pim-1-mediated activation of the c-Myc signaling pathway. J Biol Chem 274: 18659-18666, 1999.

8. Zhang Y, Wang Z and Magnuson NS: Pim-1 kinase-dependent phosphorylation of $\mathrm{p} 21 \mathrm{Cip} 1 / \mathrm{WAF} 1$ regulates its stability and cellular localization in H1299 cells. Mol Cancer Res 5: 909-922, 2007.

9. Lilly M, Sandholm J, Cooper JJ, Koskinen PJ and Kraft A: The PIM-1 serine kinase prolongs survival and inhibits apoptosisrelated mitochondrial dysfunction in part through a bcl-2dependent pathway. Oncogene 18: 4022-4031, 1999.

10. Aho TL, Sandholm J, Peltola KJ, Mankonen HP, Lilly M and Koskinen PJ: Pim-1 kinase promotes inactivation of the proapoptotic Bad protein by phosphorylating it on the Ser112 gatekeeper site. FEBS Lett 571: 43-49, 2004.

11. Koizumi K, Hojo S, Akashi T, Yasumoto K and Saiki I: Chemokine receptors in cancer metastasis and cancer cell-derived chemokines in host immune response. Cancer Sci 98: 1652-1658, 2007.

12. Pawelek JM: Tumour-cell fusion as a source of myeloid traits in cancer. Lancet Oncol 6: 988-993, 2005.

13. Fukata M, Nakagawa M and Kaibuchi K: Roles of Rho-family GTPases in cell polarisation and directional migration. Curr Opin Cell Biol 15: 590-597, 2003.
14. Watanabe T, Noritake J and Kaibuchi K: Regulation of microtubules in cell migration. Trends Cell Biol 15: 76-83, 2005.

15. Selten G, Cuypers HT, Zijlstra M, Melief C and Berns A: Involvement of c-myc in MuLV-induced T cell lymphomas in mice: frequency and mechanisms of activation. EMBO J 3: 3215-3222, 1984.

16. Breuer M, Slebos R, Verbeek S, van Lohuizen M, Wientjens E and Berns A: Very high frequency of lymphoma induction by a chemical carcinogen in pim-1 transgenic mice. Nature 340: 61-63, 1989.

17. Wang Z, Bhattacharya N, Mixter PF, Wei W, Sedivy J and Magnuson NS: Phosphorylation of the cell cycle inhibitor p21(Cip1/WAF1) by Pim-1 kinase. Biochim Biophys Acta 1593: 45-55, 2002.

18. Stone DM, Norton LK, Magnuson NS and Davis WC: Elevated pim-1 and c-myc proto-oncogene induction in B lymphocytes from BLV-infected cows with persistent B lymphocytosis. Leukemia 10: 1629-1638, 1996.

19. Van Lohuizen M, Verbeek S, Krimpenfort P, Domen J, Saris C, Radaszkiewicz T and Berns A: Predisposition to lymphomagenesis in pim-1 transgenic mice: cooperation with c-myc and $\mathrm{N}$-myc in murine leukemia virus-induced tumors. Cell 56: 673-682, 1989.

20. Cibull TL, Jones TD, Li L, Eble JN, Ann Baldridge L, Malott SR, Luo $\mathrm{Y}$ and Cheng L: Overexpression of Pim-1 during progression of prostatic adenocarcinoma. J Clin Pathol 59: 285-288, 2006.

21. Ellwood-Yen K, Graeber TG, Wongvipat J, Iruela-Arispe ML, Zhang J, Matusik R, Thomas GV and Sawyers CL: Myc-driven murine prostate cancer shares molecular features with human prostate tumors. Cancer Cell 4: 223-238, 2003.

22. Xu Y, Zhang T, Tang H, Zhang S, Liu M, Ren D and Niu Y: Overexpression of PIM-1 is a potential biomarker in prostate carcinoma. J Surg Oncol 92: 326-330, 2005.

23. Liotta LA and Stetler-Stevenson WG: Tumor invasion and metastasis: an imbalance of positive and negative regulation. Cancer Res 51: 5054-5059, 1991.

24. Woodhouse EC, Chuaqui RF and Liotta LA: General mechanisms of metastasis. Cancer 80: 1529-1537, 1997.

25. Mehlen P and Puisieux A: Metastasis: a question of life or death. Nat Rev Cancer 6: 449-458, 2006.

26. Onken MD, Worley LA and Harbour JW: A metastasis modifier locus on human chromosome $8 \mathrm{p}$ in uveal melanoma identified by integrative genomic analysis. Clin Cancer Res 14: 3737-3745, 2008.

27. Zijlstra A, Lewis J, Degryse B, Stuhlmann H and Quigley JP: The inhibition of tumor cell intravasation and subsequent metastasis via regulation of in vivo tumor cell motility by the tetraspanin CD151. Cancer Cell 13: 221-234, 2008.

28. Hanzawa M, Shindoh M, Higashino F, Yasuda M, Inoue N, Hida K, Ono M, Kohgo T, Nakamura M, Notani K, Fukuda H, Totsuka Y, Yoshida K and Fujinaga K: Hepatocyte growth factor upregulates E1AF that induces oral squamous cell carcinoma cell invasion by activating matrix metalloproteinase genes. Carcinogenesis 21: 1079-1085, 2000.

29. Hiroumi H, Dosaka-Akita H, Yoshida K, Shindoh M, Ohbuchi T, Fujinaga $\mathrm{K}$ and Nishimura M: Expression of E1AF/PEA3, an Ets-related transcription factor in human non-small-cell lung cancers: its relevance in cell motility and invasion. Int J Cancer 93: 786-791, 2001.

30. Recio JA and Merlino G: Hepatocyte growth factor/scatter factor activates proliferation in melanoma cells through p38 MAPK, ATF-2 and cyclin D1. Oncogene 21: 1000-1008, 2002.

31. Sahai E and Marshall CJ: RHO-GTPases and cancer. Nat Rev Cancer 2: 133-142, 2002.

32. Schafer DA, Welch MD, Machesky LM, Bridgman PC, Meyer SM and Cooper JA: Visualization and molecular analysis of actin assembly in living cells. J Cell Biol 143: 1919-1930, 1998.

33. Allen WE, Jones GE, Pollard JW and Ridley AJ: Rho, Rac and Cdc42 regulate actin organization and cell adhesion in macrophages. J Cell Sci 110: 707-720, 1997.

34. Azuma T, Witke W, Stossel TP, Hartwig JH and Kwiatkowski DJ: Gelsolin is a downstream effector of rac for fibroblast motility. EMBO J 17: 1362-1370, 1998. 